\title{
A BUSINESS MODEL TO SUPPORT SUSTAINABLE PERFORMANCE OF DIGITAL STARTUP COMPANIES
}

\author{
Pri Agung Danarahmanto ${ }^{1 *}$, Yudi Aziz ${ }^{1}$ \\ ${ }^{I}$ Faculty of Economic and Business, Padjadjaran University, Bandung, Indonesia
}

(Received: November 2019 / Revised: December 2019 / Accepted: December 2019)

\begin{abstract}
Digital startup companies are faced with high failure rate. This research, therefore, aims to determine the effect of entrepreneurship orientation, innovation, customer participation, business model, and sustainable performance on startup companies. Data were qualitatively obtained using the interview from the founders of digital startup companies in Indonesia. The results showed that the business model was influenced by entrepreneurship orientation, innovation, and customer participation, while the sustainable performance was influenced by the business model. The implication of this research is the importance of developing business models by involving corporate leaders and customers to support the sustainability of digital startup companies.
\end{abstract}

Keywords: Business model; Customer participation; Digital startup; Entrepreneurship orientation, Innovation; Qualitative; Sustainable performance

\section{INTRODUCTION}

Information technology is rapidly growing in Indonesia, as seen from the growth of internet users. According to the data released by the Indonesian Internet Service Providers Association (APJII, Asosiasi Penyelenggara Jasa Internet Indonesia), in 2016 the number of internet users was 132.7 million or $52 \%$ of the total population. Internet drives the creation of new digitalrelated businesses, commonly known as profit or non-profit startup companies that create new products or services, while developing inuncertain situations (Ries, 2011). Salamzadeh and Kawamorita Kesim (2015) stated that a startup is a newly established company that always tries to maintain its existence.

According to a report made by Google Australia, Price Waterhouse Cooper, and StartupAUS, a startup company produces products or services that are different from those that currently existing, with a revenue below 5 million dollars per year. One of the developing countries in Asia that considers a startup company as an organization is India. According to the Indian government, a company is called a startup when it has been established for less than five years, with an income of 25 crore rupees or 5 billion rupiahs, and produces innovations and developments related to technology and patents.

\footnotetext{
*Corresponding author's email: priagung.dana@gmail.com
} 
One of the developing countries in Asia that defines and puts restrictions on a company so that it can be considered a startup company is India. According to Indian government, a company can be called a startup if it has been established for less than five years, has an income of 25 crore rupees or the equivalent of 5 billion rupiahs, and produces innovations and developments related to technology and patents.

Indonesia is one of the countries in the Southeast Asian region with great potential, especially in the development of digital startup companies, with tremendous attraction for investors. According to Google and Temasek data, the total investment gained by digital startup companies in Indonesia was 188 million dollars, which placed the country second after Singapore. However, it was ranked first with a total of 2,000 digital startup companies in 2015, which was larger than Singapore which was 1,800.

Many digital startup companies are creating highly innovative new business models, which allows for its sustainability and survival, accompanied by great risks (Hansen, Grosse-Dunker, \& Reichwald, 2009). In addition, not all business models are properly applied in digital startup companies, and this leads to failure such as Wavoo which was founded in 2014.

The company provided online matchmaking service combined with chat services when it was first established, which immediately attracted investors and managed to acquire funds. The company further recruited eight employees and carried out various promotions, and in a short time, it rapidly developed rapidly and attracted 2 million users. However, the company was no longer able to generate revenue because it focused on increasing the number of customers and failed to monetize the services provided, which finally led to its closure in 2016. Based on research results from Allmand Law (2013), the failure rate of digital startup companies is $90 \%$. This means that out of every ten digital startup companies, only one tends to survive and succeed. In addition, CB Insights (2019) stated that $17 \%$ of failures of digital startup companies were due to the adoption of incorrect business models. The data is supported by the research conducted by FRACTL, which stated that the application of inappropriate business model and running out of money are the main causes of failure of digital startup companies.

FRACTL mentioned that the second highest cause besides business model problems is finance which causes $24 \%$ of digital startup companies to fail due to its inability to unable to generate profits. According to Rédis (2009), revenue streams affect company performance and its level of profits and returns.

In addition to revenue problems and business models, another cause of the failure of digital startup companies is the provision of products or services that are not attractive to consumers. Based on (FRACTL) research, 18\% of digital startup companies failed due to unattractive products and services. This phenomenon is supported by CB Insights (2019) which stated that the main cause of failure of digital startup companies is related to products or services that are not needed by the market, while $14 \%$ failed because they ignored customers.

Other causes of failure of digital startup companies are innovation mistakes and the owners' lack of good entrepreneurship orientation, which makes them less proactive and aggressive in developing businesses and increasing revenues. According to Shahwan (2015), entrepreneurship orientation contributes to the design of a business model and shows the methods used by companies to generate revenue and value. The results of a survey of 30 digital startup companies showed that $77 \%$ were unable to finance their operational activities due to lack of revenue sources because the owners or leaders were oriented on gaining customers rather than creating revenue.

Based on the above explanation, the use of an incorrect business model is the main cause of failure of digital startup companies. This is because these companies often offer ideas by using 
business models and making innovations that do not meet customers' wishes. Lack of customer participation leads to low demand of products or services produced by the companies, with the inability to generate enough revenue. Another factor that also contributes to the failure of companies is lack of entrepreneurship orientation which makes the organization non-profitable and unable to survive.

The research question is based on "How innovation, entrepreneurship orientation, and customer participation affect business models in achieving the sustainability of digital startup companies in Indonesia?" To answer this question, the conditions of digital startup companies in Indonesia were examined to determine a suitable business model to achieve sustainability.

\section{LITERATURE STUDY}

\subsection{Business Model}

A business model is a story that explains how a company works and it is interpreted as a design of thoughts on how it generates revenues (Magretta, 2002). A business model is also be defined as the architecture for products, services, and various kinds of information, including an explanation of the role of the actors involved (Timmers, 1998). According to Teece (2010), a good business model is not only used as a guide for companies to run, it also needs to meet the various customer requirements. Rappa (2001) defined the business model as a method used to generate income, for the company. In this research, it is defined as an architecture that explains how a business is run to generate income.

According to Rédis (2009), the establishment of a business model in information technology companies affects performance, and it is used to determine customers' target. The author also explained several conclusions on business models. The first is the establishment of a business model and the selection of customer targets in information technology start-ups companies which tends to affect its profits and the possibility of surviving within five years. Secondly, the company's position in the supply chain determines its survival rate. Thirdly, the number of sources of income affects the company's resilience. Finally, companies with many sources of income tend to generate profits more quickly with the development of business closure lowered.

\subsection{Innovation}

The term innovation in organizations was first introduced by Schumpeter in 1934. Innovation carried out by making changes to technology, markets, and supplies tend to encourage the creation of something different in economic life (Drucker, 2014; Schumpter, 1939). In this research the notion of innovation is defined as a change in the form of the application of new ideas aimed at updating the components of the business model, while affecting the company's environment and business output.

Business innovation is influenced by internal and external factors. According to Hongqi and Ruoyu (2012), there is a positive relationship between customer participation and innovation in the company. However, the relationship shows better value when it is accompanied by customer satisfaction. Another benefit of innovation aided by customer participation is that the process incurs lower costs compared to the research process carried out by the company (Rohrbeck, Steinhoff, \& Perder, 2010).

In addition, internal factors such as entrepreneurial leadership orientation also influence innovation. According to Shahwan (2015), entrepreneurship orientation is related to innovation in companies. This statement is supported by Bouncken, Lehmann, and Fellnhofer (2016), which stated that entrepreneurship orientation influences business models, encourages innovation and new ideas. Salavou and Lioukas (2003) reported that the two components of entrepreneurship orientation that influence innovation are proactive and risk. 


\subsection{Customer Participation}

According to Fang (2008), customer participation is customer involvement in developing new products. This is also defined as an effort to engage customers in providing ideas and input on products and services provided by the company (Merlo, Eisingerich, \& Auh, 2014). Djelassi and Decoopman (2013) explained that customer participation has a significant impact in value creation, while providing services 'with the partners involved.

Based on research conducted by Foss, Laursen, and Pedersen (2011), there is a positive relationship between customer participation and innovation performance. Customer participation helps to make offers that are in accordance with their wishes to encourage the creation of superior values. According to Blazevic and Lievens (2008), the knowledge that customers have, contributes to the innovation process carried out by the company, which enables them play a role in a variety of innovation work carried out by the company. Customers' participation has a significant effect on the manufacture of new products by the company (Fang, 2008).

Another impact of utilizing customer participation in companies is increased sales. Merlo et al. (2014), stated that customer participation is very influential on the level of money spent on goods.

\subsection{Entrepreneurship Orientation}

Entrepreneurship orientation shows the tendency of companies to innovate, look for opportunities, take risks, be autonomous, and aggressive, which affects its performance (Lumpkin \& Dess, 1996). According to Shahwan (2015), the notion of entrepreneurship orientation is based on how a company makes decisions. Entrepreneurship orientation is a key strategy used to achieve organizational goals (Rauch, Wiklund, Lumpkin, \& Frese, 2009). Based on the summary of previous research, entrepreneurship orientation is defined as the perspective and attitude based on an entrepreneurial spirit to create competitive advantage.

Shahwan (2015) stated that entrepreneurship orientation is related to the design of a business model which shows how companies generate revenue and value. In addition, Nur and Salim (2014) stated that companies need to adopt an entrepreneurship orientation to determine new opportunities and gain profit. Bouncken et al. (2016) found the relationship between entrepreneurship orientation with the ability to encourage the creation of value and the proportion for companies to make offers or new business models.

\subsection{Sustainable Performance}

Sustainable performance is the extent to which the business owner or entrepreneur maintains economic and social performance over a long term (Thongpoon, 2012). According to Hall, Daneke, and Lenox (2010), sustainable performance is analyzed from three objectives, namely social, economic, and environment. Data obtained from previous studies showed that the financial and non-financial performace are the two dimensions and indicators used as benchmarks for sustainability (Ahmad, 2007; Shahwan, 2015; Teeratansirikool, Siengthai, Badir, \& Charoenngam, 2013). In Santos and Brito (2012) used the dimensions of social and environmental performance as a complementary measure to analyze a company's sustainability.

Financial and non-financial conditions of a company play a role in determining its sustainable performance. Teeratansirikool et al. (2013) stated that financial conditions are more influential on companies than non-financial conditions. 


\section{METHODOLOGY}

This research used a qualitative approach which is a procedure that produces descriptive data on the observed subject, in the form of written or oral words (Moleong, 2007). Guba and Lincoln (1981) defined the qualitative study as a method used to obtain a view of the subject being studied with in-depth description of the assessment. Data were obtained from the leaders of Wavoo by using the interview method to explore the background, business development, opportunities, and obstacles that occurred in the digital startup of the company.

The interviewer conducted face-to-face interview with the informant using a semi-structured pattern. This means that the interviewer had prepared several questions that were developed more openly to explore opinions and ideas from the informant. The data collected were analyzed by organizing, making patterns and by making conclusions, for proper understanding when shared with others (Bogdan \& Biklen, 1992).

\section{RESULT AND DISCUSSION}

\subsection{Wavoo's Business Model}

Wavoo was a company that offered portal services for users to get acquainted and determine a mate with variety of features to facilitate the introduction process, such as chat services. Its service was offered free service, which attracted lots of users. However, the company failed to monitze its services, either through the sale of paid services or data analysis as conducted by other big companies.

Wavoo's business model was influenced by the factors of investors as funders. Its phases from the first to the last year were described as follows. The first phase prepared human resources and formed a team. This phase occurred frm the first to the sixth month of investment with investors agreeing to pay investment costs to organize a team, looking for human resources in accordance with the operational needs of the company. This was conducted to accelerate the product development process for immediate introduction to the public. In this phase, Wavoo was not monetized because some of the products were still in the development stage, therefore, the company relied on investor funds to pay operational costs.

The second phase introduced the application and multiplied its users. This phase occurred in the second, seventh, and twelfth month of the investment, with a target ofone million users. This target led to an increase in the number of employee to raise the marketing resources. At this phase, the company wasted investment money by conducting various promotions through mass/online media, and by holding events. Various methods were used to increase user growthwhich is an important parameter for digital startup companies. In this phase, the Wavoo application was used free of charge and the company failed to make sales in the application, therefore, operational costs were borne by the investment provided by investors.

The third phase added users and monetizied the system in the second year or between the thirteenth and twenty-fourth month since the investment started. In this phase, investors gave a target for Wavoo to increase user number to two million and the company was expected to monetize the program to generate and reduce the burden on investors in financing the company's operations. To achieve this target, Wavoo started issuing several paid services such as the purchase of paid stickers and chat services, while increasing the number of users to measure growth and value. With this data, the company was monetized by offering advertising services and selling customer data analysis.

Based on the phases of company development, it is concluded that Wavoo was a user-oriented company, as shown in the two years operation with little monetization. The company was able to monetize the application by offering paid products and creating advertising services. 


\subsection{The Failure of Wavoo Business Model}

Customer growth for digital startups is important, however, it needs to be balanced with the revenue generated. In the first and second phases, Wavoo managed to reach the target of one million customers as provided by its investors in the first year. The company however, developed problems in the second year due to its failed attempt to reach the target desired by investors.

In the second year, investors asked the company to increase the number of users to two million and monetize to generate revenue. Although it succeded in gaining two million users, it failed to monetize the system, despite selling paid stickers and premium services.

In the third phase in the period of one year, Wavoo utilized two ways to generate income. This showed that the company was not creative and lacked innovation in an effort to increase revenue. Based on the above facts, it is stated that Wavoo did not have a good entrepreneurship orientation. According to Nur and Salim (2014), entrepreneurship orientation is significantly related to company performance. Bouncken et al. (2016) stated that entrepreneurship orientation has several indicators, namely innovation, proactivity, and risk-taking, while Shahwan (2015) reported that the view of the future is also an indicator of entrepreneurship orientation. Wavoo was not innovative and proactive because it failed to gain adequate income for its continuous existence.

The two paid services offered by Wavoo were not attractive to customers as evidenced by the minimal amount of monthly income derived from the sale of stickers and paid services. In an interview conducted with the CTO, the company failed to carry out survey to obtain input from potential and existing customers because it was too busy adding the number of users. This means that Wavoo did not involve customers in innovating and developing products leading to failure. Paid stickers and premium services were not attractive to customers, therefore, they rarely used them which led to lack of company revenue. According to Fang (2008), companies need customer participation in product development by involving them as a source of information and as co-developers. Customers' knowledge contributes to the innovation process carried out by the company, therefore, they play vital roles in the work carried out by the company (Blazevic \& Lievens, 2008). Wavoo failed to exploit the potential of its two million users to innovate and develop products. However, the company ignored customer participation and in addition, they were not interested in the products.

Revenues generated from the sales of paid stickers and premium services were unable to cover operational costs, such as employee salaries and server rents. Lack of income caused the company to rely too much on funds provided by its investors, and problemsarose when the targets provided by the investors were not achieved. As a result, the investors lost confidence and led to a reduction in investment, thereby, leading to the company's inability to pay for its operating costs.

In addition, there were also other internal problems, such as transparency in investment funds, with poor entrepreneurship that was not oriented towards the company's future. Accumulation of various things, namely lack of innovation, revenue sources, customer participation, and transparency of investment funds resulted in loss of investor trust and withdrawal from the company.

Withdrawal of investment funds froze the company's operations due to inadequate source of income (Rédis, 2009). According to Santos and Brito (2012), finance is significantly related to profitability and growth, compared to other variables. When income is sufficient, the company has the ability to pay for operational costs and continue to develop products to survive and achieve business continuity. 


\section{CONCLUSION AND RECOMMENDATIONS}

\subsection{Conclusion}

In conclusion, this article analyzes the failure associated with a digital startup company, using Wavoo as a case study. The company's failure was triggered by the adoption of a business model not supported by entrepreneurship orientation, innovation, and customer participation. In addition, the main business model was equipped with several paid services and failed to function properly, thereby, affecting the sustainability of the company's performance.

The findings of this case study showed that digital startup companies are not future-oriented and are vulnerable to failure when it pays attention to users alone. Wavoo tended to sacrifice income and did very little innovation to increase revenue streams, therefore, it did not have adequate income to support its existence. In this research, it is seen that innovation plays a significant role in determining the future of start-up companies because they are engaged in the digital industry that is very dynamic. Innovation is also needed to adjust market needs, therefore, it needs to also involve customers to encourage them to buy or use their products.

Changes made by the company in the form of adjustments to various components in the business model needs to involve customers for sustainable performance.

The leader of the start-up company plays an important role in determining the continuity of the company as the founder and investor. In addition, the company did not have many employees, therefore, the various decisions and considerations were depended on the leader alons. Therefore, start-up companies need a leader with good entrepreneurship orientation, to encourage the production of a business model based on innovation and oriented on customer participation.

\subsection{Recommendations}

Digital startup companies need to apply a business model that is supported by entrepreneurship orientation, innovation, and customer participation. The business model needs the support of proactive leaders that are willing to take risks, and with the ability to carry out its vision and mission continuously by involving customers.

Digital startup companies need to balance the increase in the number of new customers and revenue. This is conducted by applying a business model with more than three revenue streams, to reduce the risk of income shortages. The authors suggest that digital startups strikes a balance between customer growth and revenue, therefore, they are able to monetize its usageand conduct business activities that make money directly, such as selling real digital products.

A company's financial condition influences its performance. Financial conditions are more influential on companies due to its ability to make futuer predictions. It is recommended that future research need to emphasize on determinng business models that are suitable for digital startup companies, especially in developing countries. It is expected that further research has the ability to determine the structure of business models and the factors that minimize the number of failures of digital startup companies caused by financial conditions.

\section{REFERENCES}

Ahmad, N. H. (2007). A cross cultural study of entrepreneurial competencies and entrepreneurial success in SMEs in Australia and Malaysia.

Allmand Law. (2013). Mapping Tech Startups. Retrieved from https://www.allmandlaw.com/blog/2013/january/mapping-tech-startups.aspx 
Blazevic, V., \& Lievens, A. (2008). Managing innovation through customer coproduced knowledge in electronic services: An exploratory study. Journal of the Academy of Marketing Science, 36(1), 138-151.

Bogdan, R. C., \& Biklen, S. (1992). Qualitative Reserach for Education: An Introduction to the Theory and Methods. In: Boston: Allyn and Bacon.

Bouncken, R. B., Lehmann, C., \& Fellnhofer, K. (2016). The role of entrepreneurial orientation and modularity for business model innovation in service companies. International Journal of Entrepreneurial Venturing, 8(3), 237-260.

CB Insights. (2019). The Top 20 Reasons Startups Fail. Retrieved from https://www.cbinsights.com/research/startup-failure-reasons-top/

Djelassi, S., \& Decoopman, I. (2013). Customers' participation in product development through crowdsourcing: Issues and implications. Industrial Marketing Management, 42(5), 683692.

Drucker, P. (2014). Innovation and entrepreneurship: Routledge.

Fang, E. (2008). Customer participation and the trade-off between new product innovativeness and speed to market. Journal of marketing, 72(4), 90-104.

Foss, N. J., Laursen, K., \& Pedersen, T. (2011). Linking customer interaction and innovation: The mediating role of new organizational practices. Organization Science, 22(4), 980-999.

FRACTL. Decoding Startup Failure: Why 193 Failed Startups Didn't Survive. Retrieved from https://www.frac.tl/work/marketing-research/why-startups-fail-study/

Guba, E. G., \& Lincoln, Y. S. (1981). Effective evaluation: Improving the usefulness of evaluation results through responsive and naturalistic approaches: Jossey-Bass.

Hall, J. K., Daneke, G. A., \& Lenox, M. J. (2010). Sustainable development and entrepreneurship: Past contributions and future directions. Journal of Business Venturing, 25(5), 439-448.

Hansen, E. G., Grosse-Dunker, F., \& Reichwald, R. (2009). Sustainability innovation cube-a framework to evaluate sustainability-oriented innovations. International Journal of Innovation Management, 13(04), 683-713.

Hongqi, Z., \& Ruoyu, L. (2012). Empirical research of the relationship between customer participation, customer satisfaction and service innovation performance in China. African Journal of Business Management, 6(4), 1449-1454.

Lumpkin, G. T., \& Dess, G. G. (1996). Clarifying the entrepreneurial orientation construct and linking it to performance. Academy of management Review, 21(1), 135-172.

Magretta, J. (2002). Why business models matter. In: Harvard Business School Boston, MA.

Merlo, O., Eisingerich, A. B., \& Auh, S. (2014). Why customer participation matters. MIT Sloan Management Review, 55(2), 81.

Moleong, L. J. (2007). Qualitative Research Methodology. Bandung: PT Remaja Rosdakarya, 103.

Nur, N., \& Salim, U. (2014). Entrepreneurship Orientation, Market Orientation, Business Strategy, Management Capabilities On Business Performance; Study At Small And Medium Enterprise Printing In Kendari. International Journal of Business and Management Invention, 3(12), 8-17.

Rappa, M. (2001). Business models on the Web. Retrieved from http://digitalenterprise.org/models/models.html

Rauch, A., Wiklund, J., Lumpkin, G. T., \& Frese, M. (2009). Entrepreneurial orientation and business performance: An assessment of past research and suggestions for the future. Entrepreneurship theory and practice, 33(3), 761-787.

Rédis, J. (2009). The impact of business model characteristics on IT firms' performance. International journal of business, 14(4), 291. 
Ries, E. (2011). The lean startup: How today's entrepreneurs use continuous innovation to create radically successful businesses: Crown Books.

Rohrbeck, R., Steinhoff, F., \& Perder, F. (2010). Sourcing innovation from your customer: how multinational enterprises use Web platforms for virtual customer integration. Technology Analysis \& Strategic Management, 22(2), 117-131.

Salamzadeh, A., \& Kawamorita Kesim, H. (2015). Startup companies: Life cycle and challenges. Paper presented at the 4th International conference on employment, education and entrepreneurship (EEE), Belgrade, Serbia.

Salavou, H., \& Lioukas, S. (2003). Radical product innovations in SMEs: the dominance of entrepreneurial orientation. Creativity and innovation management, 12(2), 94-108.

Santos, J. B., \& Brito, L. A. L. (2012). Toward a subjective measurement model for firm performance. BAR-Brazilian Administration Review, 9(SPE), 95-117.

Schumpter, J. A. (1939). Business Cycles; a Theoretical Historical and Statistical Analysis of the Capitalist Process: New York, McGraw-Hill.

Shahwan, R. M. (2015). Novel business models: an empirical study of antecedents and consequences. Newcastle University,

Teeratansirikool, L., Siengthai, S., Badir, Y., \& Charoenngam, C. (2013). Competitive strategies and firm performance: the mediating role of performance measurement. International Journal of Productivity and Performance Management, 62(2), 168-184.

Thongpoon, S. (2012). Sustainable performance of Thai SMEs: Investigating the entrepreneurial competencies and sufficiency economy philosophy. Asia Pacific Journal of Management \& Entrepreneurship Research, 1(2), 5.

Timmers, P. (1998). Business models for electronic markets. Electronic Markets, 8(2), 3-8. 